\title{
House Republicans float proposal for single Department of Science
}

Washington. A proposal to establish a Department of Science to oversee most federal science and technology programmes is gaining ground in the US Congress, where several powerful Republicans think it could both save money and strengthen political support for science.

The idea of a science department has long been supported by the new chairman of the House of Representatives Science Committee, Robert Walker (Republican, Pennsylvania). It would also tie in with separate plans to abolish four existing government departments, including the Department of Energy. These plans were endorsed last week by Senator Robert Dole (Republican, Kansas), the majority leader in the Senate and a likely Republican candidate in next year's presidential election.

Walker and John Kasich (Republican, Ohio), chairman of the House Budget Committee, are trying to persuade those in favour of the abolition of the departments that creating a science department would be the best way to deal with the remnants of the Department of Energy, namely the energy research programme and the nuclear weapons programme.

According to Walker, the abolitionists had wanted to make the energy research programme part of the National Science Foundation. But at a recent National Space Society forum, he said that such a union would be a "mismatch". More importantly, there would be nowhere to put the nuclear weapons programme, except back in a stand-alone agency such as the former Atomic Energy Commission - which, Walker says, would not yield any administrative cost savings.

Walker is proposing a science department that would incorporate the National Aeronautics and Space Administration, the National Science Foundation and the research arms of the Environmental Protection Agency and the energy and commerce departments. The National Institutes of Health would not be included.

The idea of a single government department controlling the bulk of research funds is feared by many scientists, who argue that US science has benefited immensely from the diversity of available funding sources. But advocates say that science would benefit from administrative savings, from having a cabinet-ranking science secretary and from a budget allocation which would be dedicated to science and therefore - the argument goes - less prone to attack in Congress.

Walker has not yet finalized his proposal. But he does expect to put forward a bill to establish a Department of Science during this session of Congress. The proposal is likely to meet opposition not only from the Clinton administration and parts of the scientific community but also from members of both houses on committees that would lose jurisdiction over the merged agencies.

Meanwhile Newt Gingrich, the leader of the House of Representatives, said last week that Walker also attended that government "should spend more in the long run on

\section{$£ 5,000$ light bulb - and it's broken!}

London. London's Science Museum has paid more than $£ 5,000$ (US\$8,100) for one of the earliest electrical light bulbs made by Thomas Edison (1847-1931).

According to Brian Bowers, senior curator of electrical engineering at the museum, a particularly significant feature of the bulb is the platinum clamps (see inset). These were Edison's solution to the problem of attaching the filament to the lead-in wires, and are only

$7 \mathrm{~mm}$ long.

The light bulb is thought to have been made in 1879. It will be displayed with a similar lamp made in 1880 but with carbon attachments for the filament.

\section{IMAGE UNAVAILABLE FOR COPYRIGHT REASONS}

R\&D, and less on partnerships with industry". He argued that the federal budget was large enough to allow this to happen, even if it were cut back and balanced. "You'd think that with $\$ 12$ trillion to spend over the next seven years, you would be able to get a fair amount done," he said.

Gingrich said that he had just come from a meeting with 100 biotechnology chief executives that had left him convinced that the government should help high technology industry by cutting capital gains tax sharply.

Accused of 'bashing' science by proposing the closure of the US Geological Survey (USGS) and the National Biological Survey (NBS), Gingrich denied that there was any proposal to shut the USGS, and said Bruce Babbitt, the interior secretary, was to blame for the pressure on the NBS. Everyone in the western United States, he said, assumed the NBS was being set up in order to produce a database that the federal government would use "to take over the ranch".

Colin Macilwain \& Tony Reichhardt

\section{MIT chemist named to head spy agency}

Washington. John Deutch, professor of chemistry at the Massachusetts Institute of Technology (MIT) and a senior research official in successive Democratic administrations, is likely to become the next director of the Central Intelligence Agency (CIA).

Deutch, who is currently deputy defence secretary with responsibility for research, was nominated as CIA director last week by President Bill Clinton. The previous nominee, Michael Carns, a retired air force general, withdrew in the face of trivial but potentially damaging allegations about the immigrant status of a family employee.

Before accepting the nomination, Belgian-born Deutch obtained agreement that if, as is considered likely, his nomination is confirmed by the Senate, the CIA director will once again become a full member of the cabinet. Friends of Deutch had previously suggested that he was worried that taking on the CIA job might jeopardize his chances of later being chosen as president of MIT.

At the Department of Defense, Deutch has tried to encourage closer cooperation between the Pentagon's vast research and development operations and the commercial sector. He was also an ardent protector of defence research in universities.

Deutch is no stranger to Washington, having been head of the Department of Energy's research office under the Carter administration.

Colin Macilwain 